University of Nebraska - Lincoln

DigitalCommons@University of Nebraska - Lincoln

Faculty Papers and Publications in Animal

Science

Animal Science Department

1996

\title{
Use of Expected Progeny Differences for Marbling in Beef: II. Carcass and Palatability Traits
}

\author{
B. L. Gwartney \\ University of Nebraska-Lincoln \\ Chris R. Calkins \\ University of Nebraska-Lincoln, ccalkins1@unl.edu \\ Richard J. Rasby \\ University of Nebraska-Lincoln, rrasby1@unl.edu \\ Rick Stock \\ University of Nebraska-Lincoln, rstock3@Unl.edu \\ B. A. Vieselmeyer \\ University of Nebraska-Lincoln \\ See next page for additional authors
}

Follow this and additional works at: https://digitalcommons.unl.edu/animalscifacpub

Part of the Animal Sciences Commons

Gwartney, B. L.; Calkins, Chris R.; Rasby, Richard J.; Stock, Rick; Vieselmeyer, B. A.; and Gosey, James A., "Use of Expected Progeny Differences for Marbling in Beef: II. Carcass and Palatability Traits" (1996). Faculty Papers and Publications in Animal Science. 590.

https://digitalcommons.unl.edu/animalscifacpub/590

This Article is brought to you for free and open access by the Animal Science Department at DigitalCommons@University of Nebraska - Lincoln. It has been accepted for inclusion in Faculty Papers and Publications in Animal Science by an authorized administrator of DigitalCommons@University of Nebraska - Lincoln. 


\section{Authors}

B. L. Gwartney, Chris R. Calkins, Richard J. Rasby, Rick Stock, B. A. Vieselmeyer, and James A. Gosey 


\title{
Use of Expected Progeny Differences for Marbling in Beef: II. Carcass and Palatability Traits ${ }^{1,2,3}$
}

\author{
B. L. Gwartney, C. R. Calkins4, R. J. Rasby, R. A. Stock, \\ B. A. Vieselmeyer, and J. A. Gosey
}

Department of Animal Science, University of Nebraska, Lincoln 68583-0908

\begin{abstract}
A 2-yr study was conducted to determine the effect of EPD for marbling on marbling score, palatability traits, and carcass fatness in beef. Steer ( $\mathrm{n}=122)$ and heifer $(\mathrm{n}=123)$ carcasses were obtained by mating Angus bulls having a high (>.4) or low (<-.16) EPD for marbling to MARC II cows ( $1 / 4$ Angus, $1 / 4$ Hereford, 1/4 Simmental, and 1/4 Gelbvieh). Carcass traits, composition of primals, quarters, and sides, palatability, and shear force data were obtained and adjusted to the mean number of days on feed, equal marbling score (Small50), fat thickness (1.0 $\mathrm{cm})$, and carcass weight $(318 \mathrm{~kg}$ ) end points. Steer carcasses from the high marbling EPD group, adjusted to the mean number of days on feed, had significantly more marbling $(P<.01)$ and less subcutaneous fat in the side and the hindquarter $(P<.10)$ than their low marbling EPD counterparts. Adjusting steers to

Small 50 marbling produced smaller longissimus muscle area (by $5 \mathrm{~cm}^{2}$ ), less fat thickness (1.15 vs 1.28 $\mathrm{cm}$ ), and lighter side weights (306 vs $333 \mathrm{~kg}$ ) for high marbling vs low marbling EPD groups, indicating a faster rate of marbling deposition. Similar relationships of a greater magnitude were found for heifers, perhaps because the heifers were older than the steers at slaughter. No differences in taste panel ratings or shear force values were noted among steer carcasses. Heifer carcasses from the high marbling EPD group had better $(P<.05)$ ratings for juiciness, muscle fiber tenderness, and overall tenderness than the low marbling EPD group heifers. These results indicate that it is possible, using existing genetic resources, to maintain marbling score and decrease fat in other depots of the carcass without compromising palatability.
\end{abstract}

Key Words: Beef, Marbling, Expected Progeny Differences

J. Anim. Sci. 1996. 74:1014-1022

\section{Introduction}

Consumers of beef desire a lean, yet palatable, product. One approach is to trim excess fat from carcasses; another is to reduce fatness through genetic manipulation. As the beef industry moves toward producing leaner carcasses, care must be taken to avoid compromising palatability, an important trait to consumers.

Genetic differences in partitioning of fat among the major carcass depots have been observed in cattle by several investigators (Charles and J ohnson, 1976; Kempster et al., 1976; Tatum et al., 1986). Some have

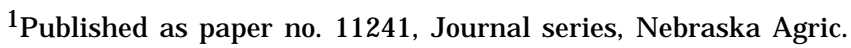
Res. Div.

${ }^{2}$ Funded in part by the Nebraska Beef Council and the American Angus Assoc.

${ }^{3}$ Appreciation is extended to R. M. Koch for his assistance with data analysis and interpretation.

${ }^{4}$ To whom correspondence should be addressed: Box 830908.

Received August 14, 1995.

Accepted J anuary 7, 1996.
}

suggested low genetic correlations between marbling and fat deposition rate in the various depots ( $L$ amb et al., 1990; Arnold et al., 1991). Therefore, selection of sires with high EPD for marbling may result in progeny with lower amounts of subcutaneous and seam fat at a constant marbling score or more marbling at constant fat thickness or carcass weight. The objective of this study was to determine the effect of sire marbling EPD on marbling score, palatability, and carcass fatness of progeny.

\section{Materials and Methods}

Animals. Six sires with high (>.4) EPD and six sires with low $(<-.16)$ EPD for marbling were selected from the 1989 American Angus Association's Sire summary. Cows and heifers (MARC II; $1 / 4$ Angus, $1 / 4$ Hereford, $1 / 4$ Simmental, and $1 / 4$ Gelbvieh) were randomly bred to 1 of the 12 sires using artificial insemination. Steer progeny $(n=122)$ and heifers ( $n$ $=123$ ) from these matings were fed in two different production systems and evaluated for carcass traits 
and composition over a 2-yr period. Details of the feeding systems, diets, and production measurements are discussed in a companion to this paper (Vieselmeyer et al., 1996). Yield and quality grade factors (USDA, 1989) of carcasses were assessed by two trained evaluators after a 72-h chill. The average was obtained from these two data collectors. Right sides from the steers and right wholesale ribs from heifers (IMPS 103; USDA, 1988) were shipped to the University of Nebraska Meat Laboratory where they were physically separated into primal cuts and dissected into lean, subcutaneous fat, intermuscular (seam) fat, and bone.

Rib Dissection and Steaks. A 9-10-11 rib section was removed according to procedures of Hankins and Howe (1946) from all of the ribs and dissected into lean, subcutaneous fat, seam fat, and bone components. The remaining portion of the rib was also dissected and the composite of the 9-10-11 rib and the remaining rib were used in analysis of tissue depots. A 2.5-cm-thick portion of the longissimus muscle was obtained from the 12th rib section, trimmed of all visible fat and connective tissue, and analyzed for lipid and moisture content (AOAC, 1985). The longissimus from 9-10-11 rib section was trimmed of all fat and sliced (usually 4 or 5 ) into $2.5-\mathrm{cm}$ steaks starting at the posterior end, labeled, and frozen until further textural and sensory analysis.

Shear Force and Cooking. Warner-Bratzler shear force ( SFV) evaluation was performed each year and only after all steaks from that year were obtained. Steaks used for SFV determination were tempered 24 $\mathrm{h}$ at $4^{\circ} \mathrm{C}$ and then cooked on Farberware Open Hearth broilers to an internal temperature of $70^{\circ} \mathrm{C}$ (AMSA, 1978). Internal temperature was monitored using copper/constantan thermocouples placed in the center of the steak. Cooked steaks were cooled to $21^{\circ} \mathrm{C}$ and 8 to $101.27-\mathrm{cm}$ cores were removed parallel to fiber orientation and sheared using a Warner-Bratzler shear attachment to an Instron Universal Testing Machine. The Instron unit was calibrated to a full scale load of 1 using a 500-kg load cell, a crosshead speed of $250 \mathrm{~mm} / \mathrm{min}$, and 2:1 chart speed ratio.

Sensory. A descriptive attribute panel was trained and tested according to methods of AMSA (1978) and Cross et al. (1978) in each of the $2 \mathrm{yr}$. After 1 wk of training, triangle tests were used to further evaluate training progress. Upon completion of training, 10 panelists were selected for the trained panel evaluation.

For sensory analysis, steaks were tempered and cooked as previously described for textural analysis. At each panel session, steaks were sliced into $1 \times 1 \times 2$ $\mathrm{cm}$ cubes using a plastic template and placed in double boilers until served ( $<30 \mathrm{~min}$ ). Two cubes from each of six randomly sampled steaks were presented to 10 panelists to evaluate. Panelists evaluated muscle fiber tenderness, connective tissue amount, overall tenderness, and juiciness on 8-point rating scales ( $8=$ extremely tender, no connective tissue, extremely tender, or extremely juicy, 1 = extremely tough, abundant connective tissue, extremely tough, or extremely dry, respectively).

Statistics. Means of response variables were adjusted to the mean number of days on feed within the steer and heifer groups. This allowed comparison of the two populations through comparison of standard errors. Following the method described by Koch et al. (1979), age-adjusted carcass traits were regressed on days on feed. This allowed adjustment of means to alternative carcass end points. Regressions were used to estimate values that would have been obtained if all animals within a sex class and EPD group had been fed fewer or more days until the average reached a given end point with regard to carcass weight (318 $\mathrm{kg})$, fat thickness $(1.0 \mathrm{~cm})$, or marbling score (Small50). Because the goal was to compare the sex Class/EPD groups, the average regression within a sex class was modified by a proportionate adjustment of the EPD group mean to the general mean as follows: $\hat{y}_{i}=\left(y_{i} / y_{\mu}\right) \cdot\left[y_{\mu}+b_{\mu}(D-d)\right]$, where $\hat{y}_{i}$ is the adjusted mean of the $i^{\text {th }}$ EPD group, $y_{i}$ is the age-constant least squares mean of the $i^{\text {th }}$ EPD group, $\mathrm{y}_{\mu}$ is the least squares mean for both EPD groups, $b_{\mu}$ is the average regression coefficient over both EPD groups, D is the number of days on feed required to reach a given end point, and $d$ is the average number of days fed.

The number of days on feed required to reach a given end point can be derived by substituting the end point in the equation for $\hat{y}_{i}$ and solving for $D$. The derived $D$ is then used in the equation for traits other than the end point.

The means adjusted to various carcass end points are presented here to demonstrate the direction and magnitude of the change in traits as influenced by carcass weight, fat thickness, and marbling score. Sampling errors of adjusted means can be developed from the sampling errors of the average EPD group regression coefficients. These sampling errors were not calculated, but are increased by the square of the deviation of days to reach the alternative end points (Koch et al., 1979). The errors of these differences are, thus, influenced by selection of the end point (i.e., deviation from the overall mean) and therefore follow predictable trends for the two groups from the ageconstant values, The results of this analysis are applicable to the population within this study, not to future or other sires of the Angus breed.

\section{Results and Discussion}

Carcass traits, such as fat thickness and marbling score, are moderately heritable. Lamb et al. (1990) reported heritability estimates of .24 to .33 for fat thickness, carcass weight, ribeye area, and marbling. Arnold et al. (1991) reported similar results with heritabilities of .49 and .46, respectively for fat 
Table 1. Least squares means of steer carcass traits adjusted to a common days on feed, carcass weight, fat thickness, or marbling end point

\begin{tabular}{|c|c|c|c|c|c|}
\hline Trait, $\mu, \mathrm{b}$ & $\begin{array}{l}\text { EPD } \\
\text { group }\end{array}$ & $\begin{array}{c}\text { Days on } \\
\text { feed }=157\end{array}$ & $\begin{array}{c}\text { Carcass } \\
\text { weight }=318 \mathrm{~kg}\end{array}$ & $\begin{array}{l}\text { Fat thickness } \\
\quad=1.0 \mathrm{~cm}\end{array}$ & $\begin{array}{l}\text { Marbling } \\
\text { score }=\mathrm{Sm}^{50}\end{array}$ \\
\hline \multicolumn{6}{|c|}{ Longissimus muscle area, $\mathrm{cm}^{2}$} \\
\hline$\mu=76.4 \pm .66$ & High & $75.79 \pm .93$ & 77.38 & 72.72 & 75.65 \\
\hline $\mathrm{b}=.1294 \pm .020$ & Low & $77.10 \pm .95$ & 78.27 & 74.59 & 80.51 \\
\hline \multicolumn{6}{|c|}{ Adjusted fat thickness, $\mathrm{cm}$} \\
\hline$\mu=1.14 \pm .03$ & High & $1.15 \pm .041$ & 1.23 & 1.0 & 1.15 \\
\hline $\mathrm{b}=.0064 \pm .001$ & Low & $1.12 \pm .042$ & 1.17 & 1.0 & 1.28 \\
\hline \multicolumn{6}{|c|}{ Kidney, pelvic, and heart fat, \% } \\
\hline$\mu=2.08 \pm .03$ & High & $2.12 \pm .046$ & 2.18 & 2.00 & 2.11 \\
\hline $\mathrm{b}=.0048 \pm .001$ & Low & $2.05 \pm .047$ & 2.09 & 1.96 & 2.17 \\
\hline \multicolumn{6}{|l|}{ Side weight, $\mathrm{kg}$} \\
\hline$\mu=308.64 \pm 2.23$ & High & $307.2 \pm 3.12$ & 318 & 286.4 & 306.3 \\
\hline $\mathrm{b}=.876 \pm .067$ & Low & $310.1 \pm 3.18$ & 318 & 293.1 & 333.0 \\
\hline \multicolumn{6}{|l|}{ Yield grade } \\
\hline$\mu=2.88 \pm .05$ & High & $2.92 \pm \quad .069$ & 3.02 & 2.72 & 2.91 \\
\hline $\mathrm{b}=.0083 \pm .001$ & Low & $2.83 \pm .071$ & 2.91 & 2.67 & 3.04 \\
\hline \multicolumn{6}{|l|}{ Marbling score $\mathrm{b}^{\mathrm{b}}$} \\
\hline$\mu=332.99 \pm 6.35$ & High & $351.6 \pm 8.89^{c}$ & 370.6 & 315.1 & 350 \\
\hline $\mathrm{b}=1.448 \pm .190$ & Low & $314.4 \pm 9.07^{d}$ & 326.6 & 288.0 & 350 \\
\hline
\end{tabular}

${ }^{a} E P D=$ expected progeny difference.

$\mathrm{b}_{200}=$ slight $^{00}, 300=$ small $^{00}$.

$c, d$ Means for the same trait in the same column bearing different superscripts differ $(P<.01)$.

thickness and longissimus muscle area. Estimates of the genetic correlation between fat thickness and marbling have differed considerably. Lamb et al.
(1990) estimated the genetic correlation to be .73, whereas Arnold et al. (1991) found it to be .19. The hypothesis of this research was that it may be possible

Table 2. Least squares means of heifer carcass traits adjusted to a common days on feed, carcass weight, fat thickness, or marbling end point

\begin{tabular}{|c|c|c|c|c|c|}
\hline Trait, $\mu, \mathrm{b}$ & $\begin{array}{l}\text { EPD } \\
\text { group }^{a}\end{array}$ & $\begin{array}{l}\text { Days on } \\
\text { feed }=107\end{array}$ & $\begin{array}{c}\text { Carcass } \\
\text { weight }=318 \mathrm{~kg}\end{array}$ & $\begin{array}{l}\text { Fat thickness } \\
\quad=1.0 \mathrm{~cm}\end{array}$ & $\begin{array}{c}\text { Marbling } \\
\text { score }=\mathrm{Sm}^{50}\end{array}$ \\
\hline $\begin{array}{l}\text { Longissimus muscle area, } \mathrm{cm}^{2} \\
\begin{aligned} \mu & =81.7 \pm .72 \\
\mathrm{~b} & =.1817 \pm .0228\end{aligned}\end{array}$ & $\begin{array}{l}\text { High } \\
\text { Low }\end{array}$ & $\begin{array}{ll}80.27 \pm & 1.04^{c} \\
83.06 \pm & 1.00^{d}\end{array}$ & $\begin{array}{l}83.82 \\
84.34\end{array}$ & $\begin{array}{l}80.38 \\
81.42\end{array}$ & $\begin{array}{l}79.16 \\
88.84\end{array}$ \\
\hline $\begin{array}{l}\text { Adjusted fat thickness, } \mathrm{cm} \\
\mu=1.03 \pm .026 \\
\mathrm{~b}=.0077 \pm .001\end{array}$ & $\begin{array}{l}\text { High } \\
\text { Low }\end{array}$ & $\begin{array}{ll}1.00 \pm & .038 \\
1.07 \pm & .036\end{array}$ & $\begin{array}{l}1.14 \\
1.13\end{array}$ & $\begin{array}{l}1.0 \\
1.0\end{array}$ & $\begin{array}{r}.95 \\
1.32\end{array}$ \\
\hline $\begin{array}{l}\text { Kidney, pelvic, and heart fat, \% } \\
\begin{aligned} \mu & =2.14 \pm .04 \\
\mathrm{~b} & =.0068 \pm .0011\end{aligned}\end{array}$ & $\begin{array}{l}\text { High } \\
\text { Low }\end{array}$ & $\begin{array}{ll}2.09 \pm & .052 \\
2.19 \pm & .050\end{array}$ & $\begin{array}{l}2.22 \\
2.23\end{array}$ & $\begin{array}{l}2.10 \\
2.12\end{array}$ & $\begin{array}{l}2.05 \\
2.40\end{array}$ \\
\hline $\begin{array}{l}\text { Side weight, } \mathrm{kg} \\
\mu=305.14 \pm 2.32 \\
\mathrm{~b}=.969 \pm .074\end{array}$ & $\begin{array}{l}\text { High } \\
\text { Low }\end{array}$ & $\begin{array}{l}299.1 \pm 3.36^{\mathrm{e}} \\
311.2 \pm 3.21^{\mathrm{f}}\end{array}$ & $\begin{array}{l}318 \\
318\end{array}$ & $\begin{array}{l}299.7 \\
302.4\end{array}$ & $\begin{array}{l}293.2 \\
342.1\end{array}$ \\
\hline $\begin{array}{l}\text { Yield grade } \\
\mu=2.50 \pm .05 \\
\mathrm{~b}=.0082 \pm .0015\end{array}$ & $\begin{array}{l}\text { High } \\
\text { Low }\end{array}$ & $\begin{array}{ll}2.47 \pm & .069 \\
2.53 \pm & .066\end{array}$ & $\begin{array}{l}2.63 \\
2.58\end{array}$ & $\begin{array}{l}2.47 \\
2.45\end{array}$ & $\begin{array}{l}2.41 \\
2.79\end{array}$ \\
\hline $\begin{array}{l}\text { Marbling score } \mathrm{b}^{\mathrm{s}} \\
\mu=333.34 \pm 6.95 \\
\mathrm{~b}=1.511 \pm .221\end{array}$ & $\begin{array}{l}\text { High } \\
\text { Low }\end{array}$ & $\begin{array}{l}360.1 \pm 10.099 \\
306.6 \pm 9.57^{h}\end{array}$ & $\begin{array}{l}392.6 \\
316.2\end{array}$ & $\begin{array}{l}361.2 \\
294.2\end{array}$ & $\begin{array}{l}350 \\
350\end{array}$ \\
\hline
\end{tabular}

${ }^{\mathrm{a}} \mathrm{EPD}=$ expected progeny difference.

$\mathrm{b}_{200}=$ slight $^{00}, 300=$ small 00 .

$c, d$ Means for the same trait in the same column bearing different superscripts differ $(P<.10)$.

$\mathrm{e}, \mathrm{f}$ Means for the same trait in the same column bearing different superscripts differ $(P<.05)$.

$g, h_{M e a n s}$ for the same trait in the same column bearing different superscripts differ $(P<.01)$. 
Table 3. Least squares means of steer side and hindquarter composition adjusted to a common days on feed, carcass weight, fat thickness, or marbling end point

\begin{tabular}{|c|c|c|c|c|c|}
\hline Trait, $\mu, \mathrm{b}$ & $\begin{array}{l}\text { EPD } \\
\text { group }^{a}\end{array}$ & $\begin{array}{l}\text { Days on } \\
\text { feed }=157\end{array}$ & $\begin{array}{c}\text { Carcass } \\
\text { weight }=318 \mathrm{~kg}\end{array}$ & $\begin{array}{l}\text { Fat thickness } \\
\quad=1.0 \mathrm{~cm}\end{array}$ & $\begin{array}{c}\text { Marbling } \\
\text { score }=\mathrm{Sm}^{50}\end{array}$ \\
\hline \multicolumn{6}{|l|}{ Side lean, \% } \\
\hline$\mu=51.57 \pm .243$ & High & $51.64 \pm .340$ & 51.12 & 52.65 & 51.69 \\
\hline $\mathrm{b}=-.042 \pm .007$ & Low & $51.49 \pm .346$ & 51.11 & 52.30 & 50.39 \\
\hline \multicolumn{6}{|l|}{ Side fat, \% } \\
\hline$\mu=28.04 \pm .271$ & High & $27.73 \pm .380$ & 28.36 & 26.52 & 27.68 \\
\hline $\mathrm{b}=.051 \pm .008$ & Low & $28.35 \pm .387$ & 28.82 & 27.35 & 29.71 \\
\hline \multicolumn{6}{|l|}{ Side seam fat, $\%$} \\
\hline$\mu=18.10 \pm .177$ & High & $18.00 \pm .249$ & 18.35 & 17.33 & 17.97 \\
\hline $\mathrm{b}=.028 \pm .005$ & Low & $18.19 \pm .253$ & 18.45 & 17.64 & 18.93 \\
\hline \multicolumn{6}{|c|}{ Side subcutaneous fat, \% } \\
\hline$\mu=9.95 \pm .127$ & High & $9.73 \pm .178^{b}$ & 10.01 & 9.20 & 9.71 \\
\hline$b=.023 \pm .004$ & Low & $10.16 \pm .182^{C}$ & 10.37 & 9.71 & 10.78 \\
\hline \multicolumn{6}{|l|}{ Hindquarter lean, \% } \\
\hline$\mu=52.63 \pm .263$ & High & $52.73 \pm .368$ & 52.08 & 53.96 & 52.78 \\
\hline$b=-.052 \pm .008$ & Low & $52.53 \pm .375$ & 52.07 & 53.52 & 51.19 \\
\hline \multicolumn{6}{|l|}{ Hindquarter fat, \% } \\
\hline$\mu=26.33 \pm .256$ & High & $25.97 \pm .359$ & 26.48 & 24.97 & 25.92 \\
\hline $\mathrm{b}=.042 \pm .008$ & Low & $26.69 \pm .365$ & 27.07 & 25.87 & 27.80 \\
\hline \multicolumn{6}{|c|}{ Hindquarter seam fat, \% } \\
\hline$\mu=14.11 \pm .141$ & High & $14.04 \pm .198$ & 14.33 & 13.49 & 14.02 \\
\hline $\mathrm{b}=.023 \pm .004$ & Low & $14.17 \pm .202$ & 14.38 & 13.72 & 14.78 \\
\hline \multicolumn{6}{|c|}{ Hindquarter subcutaneous fat, \% } \\
\hline$\mu=12.22 \pm .154$ & High & $11.92 \pm .216^{\mathrm{b}}$ & 12.15 & 11.48 & 11.90 \\
\hline$b=.019 \pm .005$ & Low & $12.52 \pm .220^{C}$ & 12.69 & 12.15 & 13.03 \\
\hline
\end{tabular}

${ }^{\mathrm{a}} \mathrm{EPD}=$ expected progeny difference.

$b, c_{M}$ eans for the same trait in the same column bearing different superscripts differ $(P<.10)$.

to improve marbling while maintaining or even decreasing subcutaneous and seam fat.

Among steer carcasses, no differences in carcass traits were detected at the common number of days on feed, with the exception of marbling score (Table 1). Carcasses from the high marbling EPD group had significantly more marbling than those from the low marbling EPD group ( $\mathrm{P}<.01$ ). The same trends were noted when carcass traits of steers were adjusted to a constant carcass weight $(318 \mathrm{~kg})$, fat thickness $(1.0$ $\mathrm{cm}$ ), or marbling score (Small 50 ). Feeding to constant fatness seemed to retain the marbling advantage for high EPD carcasses at slightly lighter carcass weights. Correspondingly, feeding steers to a marbling-cons-

Table 4. Least squares means of steer forequarter composition adjusted to a common days on feed, carcass weight, fat thickness, or marbling end point

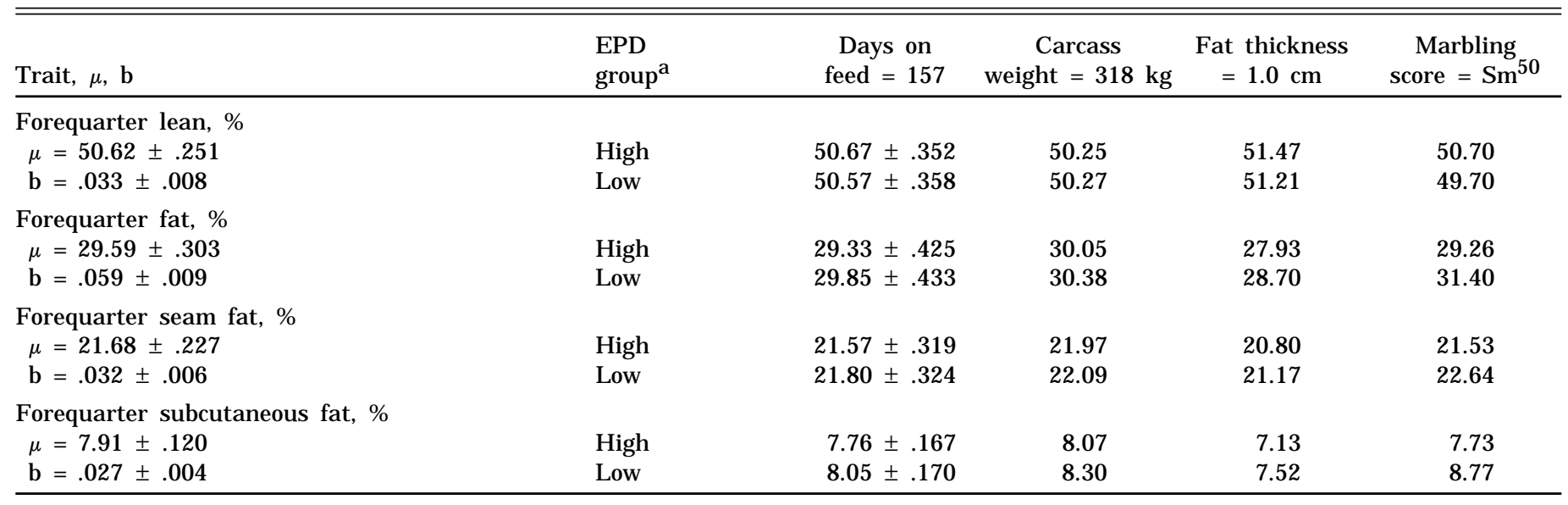

${ }^{\mathrm{a}} \mathrm{EPD}=$ expected progeny difference. 
Table 5. Least squares means of steer hindquarter primal composition adjusted to a common days on feed, carcass weight, fat thickness, or marbling end point

\begin{tabular}{|c|c|c|c|c|c|}
\hline Trait, $\mu, \mathrm{b}$ & $\begin{array}{l}\text { EPD } \\
\text { group }^{a}\end{array}$ & $\begin{array}{c}\text { Days on } \\
\text { feed }=157\end{array}$ & $\begin{array}{c}\text { Carcass } \\
\text { weight }=318 \mathrm{~kg}\end{array}$ & $\begin{array}{l}\text { Fat thickness } \\
\quad=1.0 \mathrm{~cm}\end{array}$ & $\begin{array}{c}\text { Marbling } \\
\text { score }=\mathrm{Sm}^{50}\end{array}$ \\
\hline \multicolumn{6}{|l|}{ Round lean, \% } \\
\hline$\mu=60.80 \pm .218$ & High & $60.88 \pm .306$ & 60.66 & 61.29 & 60.89 \\
\hline $\mathrm{b}=-.018 \pm .007$ & Low & $60.73 \pm .311$ & 60.58 & 61.07 & 60.28 \\
\hline \multicolumn{6}{|l|}{ Round fat, \% } \\
\hline$\mu=20.94 \pm .237$ & High & $20.67 \pm .332$ & 20.93 & 20.17 & 20.65 \\
\hline $\mathrm{b}=.021 \pm .007$ & Low & $21.21 \pm .338$ & 21.41 & 20.80 & 21.77 \\
\hline \multicolumn{6}{|l|}{ Round seam fat, \% } \\
\hline$\mu=9.47 \pm .124$ & High & $9.34 \pm .174$ & 9.50 & 9.02 & 9.33 \\
\hline $\mathrm{b}=.013 \pm .004$ & Low & $9.60 \pm .177$ & 9.72 & 9.34 & 9.56 \\
\hline \multicolumn{6}{|l|}{ Round subcutaneous fat, \% } \\
\hline$\mu=11.47 \pm .172$ & High & $11.33 \pm .240$ & 11.42 & 11.14 & 11.32 \\
\hline $\mathrm{b}=.0078 \pm .005$ & Low & $11.61 \pm .245$ & 11.68 & 11.45 & 11.82 \\
\hline \multicolumn{6}{|l|}{ Loin lean, \% } \\
\hline$\mu=55.97 \pm .296$ & High & $56.10 \pm .416$ & 55.36 & 57.54 & 56.17 \\
\hline $\mathrm{b}=-.060 \pm .009$ & Low & $55.84 \pm .423$ & 55.30 & 56.99 & 54.28 \\
\hline \multicolumn{6}{|l|}{ Loin fat, \% } \\
\hline$\mu=26.62 \pm .309$ & High & $26.33 \pm .434$ & 27.00 & 25.03 & 26.27 \\
\hline $\mathrm{b}=.055 \pm .009$ & Low & $26.91 \pm .441$ & 27.40 & 25.84 & 28.35 \\
\hline \multicolumn{6}{|l|}{ Loin seam fat, \% } \\
\hline$\mu=14.56 \pm .187$ & High & $14.47 \pm .261$ & 14.74 & 13.97 & 14.45 \\
\hline $\mathrm{b}=.021 \pm .006$ & Low & $14.65 \pm .266$ & 14.84 & 14.23 & 15.20 \\
\hline \multicolumn{6}{|l|}{ Loin subcutaneous fat, \% } \\
\hline$\mu=12.06 \pm .208$ & High & $11.85 \pm .292$ & 12.26 & 11.06 & 11.82 \\
\hline $\mathrm{b}=.034 \pm .006$ & Low & $12.26 \pm .297$ & 12.57 & 11.60 & 13.15 \\
\hline
\end{tabular}

${ }^{\mathrm{a}} \mathrm{EPD}=$ expected progeny difference.

tant end point tended to create larger longissimus muscle areas (80 vs $75 \mathrm{~cm}^{2}$ ), more subcutaneous fat thickness ( 1.28 vs $1.15 \mathrm{~cm}$ ), and heavier side weights (333 vs $306 \mathrm{~kg}$ ) for carcasses from the low marbling EPD group. This would be expected as low marbling EPD steers would not be depositing marbling as quickly as high marbling EPD steers, and thus would require longer time on feed to reach a given marbling end point. This tendency was more evident in the heifer carcasses (Table 2). For heifers, carcasses from the high marbling EPD group possessed not only more marbling, but also lighter carcasses at the mean days on feed. There was also a tendency for smaller longissimus muscle area $(P<.10)$. It is unclear whether the differences found among heifers, compared to steers, are due to a sex effect or the difference in production systems. Heifers were older at slaughter than were steers.

As with the steers, heifers from the low marbling EPD group seemed to have larger longissimus muscle areas ( 88 vs $79 \mathrm{~cm}^{2}$ ), more subcutaneous fat (1.32 vs $.95 \mathrm{~cm}$ ), and heavier side weights (342 vs $293 \mathrm{~kg}$ ) than heifers from the high marbling EPD group when adjusted to a marbling-constant end point. They also seemed to retain their marbling disadvantage at a fat thickness of $1.0 \mathrm{~cm}$ (Small ${ }^{60}$ vs Slight ${ }^{94}$ ). These data indicate that selection of sires on the basis of marbling EPD can result in carcasses attaining the Choice grade with less fat thickness and at lighter carcass weights. Conversely, progeny from sires with low EPD for marbling require more time on feed and thus are heavier at the Choice grade. These same data revealed a higher percentage Choice in the high EPD marbling group than in the low EPD marbling group (Vieselmeyer et al., 1996) when fed the same number of days. Clearly, marbling EPD are appropriate indicators of differing genetic potential to marble.

To investigate the impact of these genetic differences in marbling potential on composition, primal cuts from steer carcasses were physically separated into muscle, subcutaneous fat, seam fat, and bone. Primal data were then combined to reveal compositional differences on a side and quarter basis. Significant differences were noted for the percentage of subcutaneous fat in the side and hindquarter $(\mathrm{P}<$ .10) at constant time on feed (Table 3). For the side, hindquarter, and forequarter, steer carcasses from the high EPD group had numerically equal or higher lean percentage and equal or lower total fat, subcutaneous fat, and seam fat percentages in every case but one when adjusted to a constant marbling score, fat thickness, or carcass weight basis (Tables 3 and 4). The primal rounds and loins from carcasses in the high marbling EPD group showed the same numerical, but statistically insignificant, advantage to carcasses from the low EPD group, adjusted to the mean 
Table 6. Least squares means of steer forequarter primal composition adjusted to a common days on feed, carcass weight, fat thickness, or marbling end point

\begin{tabular}{|c|c|c|c|c|c|}
\hline Trait, $\mu, \mathrm{b}$ & $\begin{array}{l}\text { EPD } \\
\text { group }\end{array}$ & $\begin{array}{c}\text { Days on } \\
\text { feed }=157\end{array}$ & $\begin{array}{c}\text { Carcass } \\
\text { weight }=318 \mathrm{~kg}\end{array}$ & $\begin{array}{l}\text { Fat thickness } \\
\quad=1.0 \mathrm{~cm}\end{array}$ & $\begin{array}{c}\text { Marbling } \\
\text { score }=\mathrm{Sm}^{50}\end{array}$ \\
\hline \multicolumn{6}{|l|}{ Rib lean, \% } \\
\hline$\mu=49.03 \pm .279$ & High & $49.04 \pm .391$ & 48.28 & 50.49 & 49.10 \\
\hline $\mathrm{b}=-.061 \pm .008$ & Low & $49.02 \pm .398$ & 48.47 & 50.19 & 47.43 \\
\hline \multicolumn{6}{|l|}{ Rib fat, \% } \\
\hline$\mu=31.33 \pm .356$ & High & $31.32 \pm .499$ & 32.25 & 29.53 & 29.53 \\
\hline $\mathrm{b}=.075 \pm .011$ & Low & $31.35 \pm .508$ & 32.02 & 29.90 & 33.30 \\
\hline \multicolumn{6}{|l|}{ Rib seam fat, \% } \\
\hline$\mu=19.99 \pm .260$ & High & $20.09 \pm .364$ & 20.51 & 19.28 & 19.28 \\
\hline $\mathrm{b}=.034 \pm .008$ & Low & $19.89 \pm .371$ & 20.19 & 19.24 & 20.76 \\
\hline \multicolumn{6}{|c|}{ Rib subcutaneous fat, \% } \\
\hline$\mu=11.34 \pm .172$ & High & $11.23 \pm .241$ & 11.73 & 10.25 & 10.25 \\
\hline $\mathrm{b}=.041 \pm .005$ & Low & $11.46 \pm .245$ & 11.83 & 10.66 & 12.54 \\
\hline \multicolumn{6}{|l|}{ Chuck lean, \% } \\
\hline$\mu=56.87 \pm .253$ & High & $56.55 \pm .354$ & 56.32 & 57.01 & 56.57 \\
\hline $\mathrm{b}=-.019 \pm .008$ & Low & $57.18 \pm .360$ & 57.01 & 57.56 & 56.68 \\
\hline \multicolumn{6}{|l|}{ Chuck fat, \% } \\
\hline$\mu=24.72 \pm .281$ & High & $24.67 \pm .394$ & 25.09 & 23.86 & 23.86 \\
\hline $\mathrm{b}=.034 \pm .008$ & Low & $24.78 \pm .401$ & 25.08 & 24.12 & 25.66 \\
\hline \multicolumn{6}{|l|}{ Chuck seam fat, \% } \\
\hline$\mu=19.03 \pm .234$ & High & $19.04 \pm .327$ & 19.39 & 18.36 & 18.36 \\
\hline $\mathrm{b}=.028 \pm .007$ & Low & $19.02 \pm .333$ & 19.28 & 18.48 & 19.76 \\
\hline \multicolumn{6}{|c|}{ Chuck subcutaneous fat, \% } \\
\hline$\mu=5.69 \pm .132$ & High & $5.63 \pm .184$ & 5.70 & 5.49 & 5.49 \\
\hline $\mathrm{b}=.0057 \pm .004$ & Low & $5.76 \pm .188$ & 5.81 & 5.64 & 5.90 \\
\hline
\end{tabular}

${ }^{a} E P D=$ expected progeny difference.

of days on feed (Table 5). These data clearly demonstrate that identification of sires with high EPD for marbling had no adverse affects on composition of the hindquarter cuts, nor of the side.

The forequarter primal results were less clear (Table 6). Neither wholesale ribs nor chucks from the high marbling EPD steer group differed from the low marbling EPD group when adjusted to a constant number of days on feed. Neither were there many meaningful trends in the data adjusted to constant carcass weight, fat thickness, or marbling score. Thus, it seems that differences in fat distribution were more markedly affected in the hindquarter than in the forequarter. Berg et al. (1979) used regression to relate growth of depot fat to total side muscle and noted that subcutaneous fat had a higher deposition rate in the hindquarter than seam fat, whereas the opposite was true for the forequarter. Perusal of the regression coefficients for seam and subcutaneous fat in the chuck (Table 6) compared with the same coefficients for the round or loin support this contention, in that the seam fat coefficient is substantially larger than the coefficient for subcutaneous fat.

Differences in tissue distribution of fat have been studied extensively (Murphey et al., 1984; J ones et al., 1986). Fortin et al. (1981) reported that subcutaneous fat is deposited at a faster rate than seam fat. In beef carcasses, seam fat is generally the largest fat depot, followed by subcutaneous, internal, and then intramuscular fat. Heifers tend to have higher predicted percentages of seam fat than steers, and these increase as yield grades increase (J ones et al., 1986). When steer and heifer carcasses are compared at the same carcass weight, steers generally have heavier boneless primal cuts with less fat (Saul, 1983). Steers also have less channel and kidney fat, subcutaneous, seam, and intramuscular fat, and consequently less total fat, than heifers. Berg and Butterfield (1976) suggested that at equal weights or ages, heifers will be fatter than steers. This was not the case in this study, which may be due to the differences in management systems used for heifers and steers (Vieselmeyer et al., 1996).

For wholesale ribs from heifers, the differences in lean $(P<.01)$ and subcutaneous fat $(P<.10)$ were found at a constant time on feed. At constant marbling score, ribs from carcasses in the high EPD group had more lean (by $>2 \%$ ) and less fat in all depots (by more than 5\%). Berg et al. (1979) found similar relationships among steers and heifers for total side muscle to growth of depot fat.

Murphey et al. (1984) reported that heifer carcasses are often fatter than their external appearance or yield grade suggest. Similarly, J ones et al. (1986) stated that heifers had more external, intermuscular, and total fat than steers of the same yield grade. Such differences were not found in this study. For example, 
Table 7. Least squares means of heifer rib composition adjusted to a common days on feed, carcass weight, fat thickness, or marbling end point

\begin{tabular}{|c|c|c|c|c|c|}
\hline Trait, $\mu, \mathrm{b}$ & $\begin{array}{l}\text { EPD } \\
\text { group }^{a}\end{array}$ & $\begin{array}{l}\text { Days on } \\
\text { feed }=107\end{array}$ & $\begin{array}{c}\text { Carcass } \\
\text { weight }=318 \mathrm{~kg}\end{array}$ & $\begin{array}{l}\text { Fat thickness } \\
=1.0 \mathrm{~cm}\end{array}$ & $\begin{array}{c}\text { Marbling } \\
\text { score }=\mathrm{Sm}^{50}\end{array}$ \\
\hline \multicolumn{6}{|l|}{ Rib lean, \% } \\
\hline$\mu=49.97 \pm .30$ & High & $50.93 \pm .429^{d}$ & 49.23 & 50.20 & 50.55 \\
\hline $\mathrm{b}=-.050 \pm .010$ & Low & $49.02 \pm .421^{\mathrm{e}}$ & 49.37 & 50.16 & 48.15 \\
\hline \multicolumn{6}{|l|}{ Rib fat, \% } \\
\hline$\mu=29.98 \pm .34$ & High & $29.50 \pm .491$ & 31.48 & 29.57 & 28.88 \\
\hline $\mathrm{b}=.101 \pm .011$ & Low & $30.47 \pm .473$ & 31.18 & 29.55 & 33.68 \\
\hline \multicolumn{6}{|l|}{ Rib seam fat, \% } \\
\hline$\mu=19.14 \pm .24$ & High & $18.97 \pm .351$ & 20.16 & 19.01 & 18.60 \\
\hline $\mathrm{b}=.060 \pm .008$ & Low & $19.30 \pm .338$ & 19.72 & 18.76 & 21.19 \\
\hline \multicolumn{6}{|l|}{ Rib subcutaneous fat, \% } \\
\hline$\mu=10.85 \pm .16$ & High & $10.53 \pm .232^{b}$ & 11.32 & 10.56 & 10.28 \\
\hline $\mathrm{b}=.041 \pm .005$ & Low & $11.17 \pm .224^{C}$ & 11.46 & 10.79 & 12.49 \\
\hline
\end{tabular}

${ }^{a} E P D=$ expected progeny difference.

$b, c$ Means for the same trait in the same column bearing different superscripts differ $(P<.10)$.

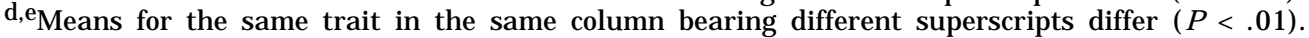

at a constant time on feed, steers had numerically lower yield grades (by about .4) compared to heifers (Tables 1 and 2), yet the percentage of the rib as separable fat was about the same for steers $(31.3 \%$, Table 6) as for heifers (30.0\%, Table 7).

Although Warner-Bratzler shear values were lower for both steers (Table 8) and heifers (Table 9) from the high EPD marbling group in all cases, these differences were not sufficiently consistent to be significant. Shear values for the heifer ribs were generally higher than those for the steers, which is consistent with the well-documented effect of animal age on tenderness.

Taste panel ratings for steaks from steers (Table 8) were not significantly different among the EPD groups, with the exception that meat from the low EPD group had better ratings for amount of connective tissue $(P<.10)$. The magnitude of this difference is probably not meaningful. Conversely, heifers from the high EPD group generated meat with more favorable $(P<.05)$ ratings of juiciness, muscle fiber tenderness, and overall tenderness. The magnitude of

Table 8. Least squares means of steer carcass shear force and taste panel traits adjusted to a common days on feed, carcass weight, fat thickness, or marbling end point

\begin{tabular}{|c|c|c|c|c|c|}
\hline Trait, $\mu, \mathrm{b}$ & $\begin{array}{l}\text { EPD } \\
\text { group }\end{array}$ & $\begin{array}{l}\text { Days on } \\
\text { feed }=157\end{array}$ & $\begin{array}{c}\text { Carcass } \\
\text { weight }=318 \mathrm{~kg}\end{array}$ & $\begin{array}{l}\text { Fat thickness } \\
\quad=1.0 \mathrm{~cm}\end{array}$ & $\begin{array}{c}\text { Marbling } \\
\text { score }=\mathrm{Sm}^{50}\end{array}$ \\
\hline \multicolumn{6}{|c|}{ Warner-Bratzler shear, kg } \\
\hline$\mu=2.34 \pm .04$ & High & $2.31 \pm .054$ & 2.31 & 2.32 & 2.31 \\
\hline $\mathrm{b}=-.00049 \pm .00116$ & Low & $2.37 \pm .055$ & 2.36 & 2.38 & 2.36 \\
\hline \multicolumn{6}{|l|}{ Taste panel juiciness } \\
\hline$\mu=5.86 \pm .07$ & High & $5.90 \pm .093$ & 5.91 & 5.87 & 5.90 \\
\hline $\mathrm{b}=.0013 \pm .0020$ & Low & $5.82 \pm .094$ & 5.83 & 5.79 & 5.80 \\
\hline \multicolumn{6}{|c|}{ Taste panel muscle fiber tenderness } \\
\hline$\mu=6.71 \pm .07$ & High & $6.75 \pm .099$ & 6.72 & 6.79 & 6.75 \\
\hline $\mathrm{b}=-.0019 \pm .0021$ & Low & $6.66 \pm .101$ & 6.65 & 6.70 & 6.61 \\
\hline \multicolumn{6}{|c|}{ Taste panel connective tissue amount } \\
\hline$\mu=7.44 \pm .03$ & High & $7.39 \pm .040^{b}$ & 7.39 & 7.38 & 7.39 \\
\hline $\mathrm{b}=.00034 \pm .00086$ & Low & $7.49 \pm .041^{c}$ & 7.49 & 7.48 & 7.50 \\
\hline \multicolumn{6}{|c|}{ Taste panel overall tenderness } \\
\hline$\mu=6.68 \pm .07$ & High & $6.72 \pm .095$ & 6.70 & 6.77 & 6.72 \\
\hline $\mathrm{b}=-.0018 \pm .0020$ & Low & $6.64 \pm .097$ & 6.63 & 6.68 & 6.60 \\
\hline \multicolumn{6}{|c|}{ Taste panel off-flavor intensity } \\
\hline$\mu=3.79 \pm .02$ & High & $3.78 \pm .024$ & 3.77 & 3.79 & 3.78 \\
\hline $\mathrm{b}=.00033 \pm .00051$ & Low & $3.80 \pm .024$ & 3.71 & 3.81 & 3.80 \\
\hline
\end{tabular}

${ }^{\mathrm{a}} \mathrm{EPD}=$ expected progeny difference.

$\mathrm{b}, \mathrm{c}_{\mathrm{M}}$ eans for the same trait in the same column bearing different superscripts differ $(\mathrm{P}<.10)$. 
Table 9. Least squares means of heifer carcass shear force and taste panel traits adjusted to a common days on feed, carcass weight, fat thickness, or marbling end point

\begin{tabular}{|c|c|c|c|c|c|}
\hline Trait, $\mu, \mathrm{b}$ & $\begin{array}{l}\text { EPD } \\
\text { group }^{a}\end{array}$ & $\begin{array}{l}\text { Days on } \\
\text { feed }=107\end{array}$ & $\begin{array}{c}\text { Carcass } \\
\text { weight }=318 \mathrm{~kg}\end{array}$ & $\begin{array}{l}\text { Fat thickness } \\
\quad=1.0 \mathrm{~cm}\end{array}$ & $\begin{array}{c}\text { Marbling } \\
\text { score }=\mathrm{Sm}^{50}\end{array}$ \\
\hline \multicolumn{6}{|l|}{ Warner-Bratzler shear, kg } \\
\hline $\mathrm{b}=-.0023 \pm .0018$ & Low & $2.97 \pm .080$ & 2.95 & 2.99 & 2.90 \\
\hline \multicolumn{6}{|l|}{ Taste panel juiciness } \\
\hline$\mu=5.63 \pm .08$ & High & $5.81 \pm .110^{b}$ & 5.93 & 5.82 & 5.78 \\
\hline$\mu=6.00 \pm .08$ & High & $6.19 \pm .118^{\mathrm{b}}$ & 6.31 & 6.19 & 6.15 \\
\hline $\mathrm{b}=.0061 \pm .0026$ & Low & $5.81 \pm .112^{C}$ & 5.85 & 5.76 & 6.00 \\
\hline \multicolumn{6}{|c|}{ Taste panel connective tissue amount } \\
\hline$\mu=7.30 \pm .04$ & High & $7.30 \pm .054$ & 7.31 & 7.30 & 7.30 \\
\hline $\mathrm{b}=-.00044 \pm .00117$ & Low & $7.30 \pm .051$ & 7.30 & 7.29 & 7.31 \\
\hline$\mu=3.81 \pm .02$ & High & $3.81 \pm .024$ & 3.81 & 3.81 & 3.81 \\
\hline $\mathrm{b}=-.000045 \pm .000521$ & Low & $3.80 \pm .023$ & 3.80 & 3.80 & 3.80 \\
\hline
\end{tabular}

${ }^{\mathrm{a}} \mathrm{EPD}=$ expected progeny difference.

$b, c_{M}$ eans for the same trait in the same column bearing different superscripts differ $(P<.05)$.

the differences among EPD groups seemed to persist at constant carcass weight and fat thickness. Adjusting the means to a constant marbling score, however, tended to minimize the differences in taste panel ratings. Others (Campion et al., 1975; Gregory et al., 1994) have reported that marbling score may have low predictive value for eating properties of meat from individual carcasses. The correlation of marbling and shear force among breed group means $(r=-.80)$ does suggest that some differences among animals with differing genetic potential to marble could potentially influence tenderness (Gregory et al., 1994). It is apparent that selection of sires with high EPD for marbling was not detrimental, and probably was beneficial, to overall tenderness of the meat.

\section{Implications}

This study indicates that it is possible to reduce carcass fatness (subcutaneous and intermuscular) while maintaining marbling and eating quality of beef by using marbling EPD when selecting sires. Therefore, producers who desire to enhance the proportion of cattle grading Choice or to minimize the amount of subcutaneous fat present when sufficient marbling for the Choice grade is achieved could benefit from this management strategy.

\section{Literature Cited}

AMSA. 1978. Guidelines for cookery and sensory evaluation of meat. American Meat Science Association and National Live Stock and Meat Board, Chicago, IL.
AOAC. 1985. Official Methods of Analysis (14th Ed.). Association of Official Analytical Chemists, Washington, DC.

Arnold, J . W., J . K. Bertrand, L. L. Benyshek, and C. Ludwig. 1991. Estimates of genetic parameters for live animal ultrasound, actual carcass data, and growth traits in beef cattle. J. Anim. Sci. 69:985.

Berg, R. T., and R. M. Butterfield. 1976. New Concepts of Cattle Growth. University of Sydney Press, Sydney, Australia.

Berg, R. T., S.D.M. J ones, M. A. Price, R. Fukuhara, R. M. Butterfield, and R. T. Hardin. 1979. Patterns of carcass fat deposition in heifers, steers and bulls. Can. J. Anim. Sci. 59:359.

Campion, D. R., J . D. Crouse, and M. E. Dikeman. 1975. Predictive value for USDA Quality Grade factors for cooked meat palatability. J. Food Sci. 40:1225.

Charles, D. D., and E. R. J ohnson. 1976. Breed differences in amount and distribution of bovine carcass and dissectible fat. J . Anim. Sci. 42:332.

Cross, H. R., R. Moen, and M. Stanfield. 1978. Training and testing of judges for sensory analysis of meat quality. Food Technol. 32: 48.

Fortin, A., J . T. Reid, A. M. Maiga, D. W. Sim, and G. H. Wellington. 1981. Effect of level of energy intake and influence of breed and sex on growth of fat tissue and distribution in the bovine carcass. J. Anim. Sci. 53:982.

Gregory, K. E., L. V. Cundiff, R. M. Koch, M. E. Dikeman, and M. Koohmaraie. 1994. Breed effects, retained heterosis, and estimates of genetic phenotypic parameters for carcass and meat traits of beef cattle. J. Anim. Sci. 72:1174.

Hankins, O. G., and P. E. Howe. 1946. Estimation of the composition of beef carcasses and cuts. USDA Tech. Bull. 926:20.

J ones, D. K., H. R. Cross, C. E. Murphey, J. W. Savell, and G. C. Smith. 1986. External and intermuscular fat trim as related to sex class and USDA yield grades for beef. J. Anim. Sci. 63 (Suppl. 1):260 (Abstr.).

Kempster, A. J ., A. Cuthbertson, and G. Harrington. 1976. Fat distribution in steer carcasses of different breeds and crosses. A review. Meat Sci. 5:83.

Koch, R. M., M. E. Dikeman, R. J erry Lipsey, D. M. Allen, and J . D. Crouse. 1979. Characterization of biological types of cattlecycle II: III. Carcass composition, quality, and palatability. J. Anim. Sci. 49:448. 
Lamb, M. A., O. W. Robison, and M. W. Tess. 1990. Genetic parameters for carcass traits in Hereford bulls. J. Anim. Sci. 68:64.

Murphey, C. E., D. D. J ohnson, G. C. Smith, H. C. Abraham, and H. R. Cross. 1984. Steer vs heifer carcass fatness differences as related to the evaluation of external fat. J . Anim. Sci. 59(Suppl. 1):244 (Abstr.).

Saul, G. R. 1983. The composition, fat distribution and yield of carcass beef from steers and heifers when entired, spayed, pregnant, or fitted with an intravaginal device. Aust. J. Exp. Anim. Husb. 23:354.
Tatum, J . D., F. L. Williams, J r., and R. A. Bowling. 1986. Effects of feeder-cattle frame size and muscle thickness on subsequent growth and carcass development. III. Partitioning of separable carcass fat. J. Anim. Sci. 62:132.

USDA. 1988. Institutional Meat Purchase Specifications. USDA, Washington, DC.

USDA. 1989. Official United States standards for grades of carcass beef. Agric. Marketing Serv., USDA, Washington, DC.

Vieselmeyer, B. A., R. J . Rasby, B. L. Gwartney, C. R. Calkins. R. A. Stock, and J. A. Gosey. 1996. Use of expected progeny differences for marbling in beef: I. Production traits. J. Anim. Sci. 74: 1013. 